\title{
Kondisi fisik kelautan habitat ditemukannya Latimeria menadoensis di selatan Teluk Manado
}

\author{
Physical oceanography condition at habitat founded of Latimeria menadoensis in the southern \\ part of Manado Bay
}

\author{
ISTI UTAMI INDAH SARI ALI*, KAWILARANG W. A. MASENGI, LUSIA MANU, ALFRET LUASUNAUNG, \\ JANNY F. POLII, REVOLS D. CH. PAMIKIRAN dan ARMAN THAMIN
}

\author{
Program Studi Pemanfaatan Sumberdaya Perikanan, Fakultas Perikanan dan Ilmu Kelautan Universitas \\ Sam Ratulangi Manado, 95115
}

\begin{abstract}
The movement of the water mass on the ocean or known as current is a very complex natural phenomenon. That related to the variation of the controlling factors. This research was based on descriptive method to obtain the information about the problem being studied. Data collected by operating the three oceanographic tools that area floater current meter, tidal gauges, and wave gauges. Data collection were carried out during the day and night of two locations which tidal and wave high were measured at $1^{\mathrm{O}} 27$ '39.90 " $\mathrm{N}$ and $124^{\mathrm{O}} 49^{\prime} 7.84^{\prime \prime} \mathrm{E}$ and $1^{\mathrm{O}} 28^{\prime} 22.86$ " $\mathrm{N}$, $124^{\circ} 48^{\prime} 40.6$ " E. Current was measured by eularian and lagrangian methods. Current pattern on the location of Latimeria menadoensis was catched shown that the current direction was eastward last quarter and contrast on fullmoon with the mean wave energy is 1.46 joule.
\end{abstract}

Keywords: lagrangian, eularian, current, wave, tide.

\begin{abstract}
ABSTRAK
Pergerakkan massa air atau dikenal dengan arus merupakan fenomena yang sangat kompleks. Hal ini berkaitan dengan besarnya variasi dari faktor-faktor pengontrol terjadinya arus di perairan. Penelitian ini dilakukan dengan metode deskriptif yaitu untuk memperoleh informasi tentang persoalan yang sedang diteliti. Pengumpulan data dilakukan dengan cara mengoperasikan tiga alat pengukur kondisi oseanografis, yaitu alat pengukur arus (floater current meter), alat pengukur pasang surut, dan alat pengukur gelombang. Pengambilan data dilaksanakan pada siang hari dan malam hari yang dilakukan pada dua titik lokasi pengambilan data yaitu, lokasi pengambilan data pasang surut dan gelombang pada titik GPS $1^{\circ} 27$ '39.90" N, $124^{\circ} 49^{\prime} 7.84^{\prime}$ E (pesisir pantai) dan lokasi pengambilan data arus metode eularian dan lagrangian pada area sekitar titik GPS $1^{\circ} 28^{\prime} 22.86$ " $\mathrm{N}, 124^{\circ} 48^{\prime} 40.6^{\prime \prime} \mathrm{E}( \pm 0,82$ mil laut dari pesisir pantai). Pola arus dimana Latimeria menadoensis tertangkap menunjukkan dominan ke arah timur pada saat perbani akhir dan berlawanan saat bulan purnama dengan energi gelombang rata-rata sebesar 1.46 joule.
\end{abstract}

Kata-kata kunci: lagrangian, eularian, arus, gelombang, pasang surut.

\section{PENDAHULUAN}

Perairan pantai merupakan salah satu wilayah perairan yang dapat digunakan untuk berbagai kepentingan seperti usaha perikanan dan pariwisata. Dalam memanfaatkan sumber daya ikan, salah satu faktor yang perlu diketahui adalah parameter oseanografi, misalnya arus atau pola aliran air.
Pola aliran juga akan berpengaruh terhadap sebaran benda-benda atau zat-zat tertentu di perairan. Bahan-bahan polutan konservatif seperti botol-botol plastik misalnya mungkin akan mengumpul pada suatu tempat atau menyebar merata disuatu tempat atau menyebar merata di suatu perairan bergantung pada pola arus (Kalangi, 2000). Pola pergerakan massa air di perairan pantai dipengaruhi oleh berbagai faktor fisik. Faktor-

*Penulis untuk penyuratan; email: istiu@yahoo.com 
faktor tersebut antara lain adalah angin, arus pasang surut (pasut), dan volume aliran sungai (Geyer, 1997). Arus berpengaruh terhadap penyebaran organisme laut (Garrison, 1993). Phytoplankton yang tidak mampu bergerak-pindah sendiri akan berdistribusi sesuai dengan pola arus. Distribusi phytoplankton ini selanjutnya akan berpengaruh terhadap distribusi organisme lainnya seperti ikan, yang terhubung dalam rantai makanan. Selain berpengaruh terhadap distribusi, arus juga berpengaruh terhadap arah renang ikan.

Metode lagrangian adalah metode pengukuran arus yang dilakukan dengan pengamatan gerakan arus permukaan dari satu titik ke titik berikutnya dalam rentan waktu tertentu (Poerbandono, 2005). Metode ini dilakukan dengan memperhitungkan jalur yang dilalui oleh setiap partikel fluida yang dinyatakan sebagai fungsi dari waktu sebagai acuan penentuan arah dan laju suatu fluida (Pickard, et al. 1990; Gross, 1990). Kalangi dan Budiman (2000) menggunakan Metode lagrangian untuk mendeskripsikan kondisi arus permukaan di perairan Teluk Manado dan pantai Tanjung Kelapa Kecamatan Tombariri Minahasa.

Coelacanth (Latimeria menadoensis) atau disebut juga sebagai ikan raja laut, adalah salah satu dari dua spesies hidup coelacanth, sejenis ikan purba, yang masih ada hingga kini. Nenek moyang terakhir dari Latimeria terdistribusi secara kontinyu disepanjang pantai yang dalam di Afrika melaui Eurasia, dimana benturan daratan India dan Eurasia tersilitasi yang disebabkan oleh sungai-sungai besar sehingga mengakibatkan habitat coelacanth terpisah dan populasi di lautan India tersebar ke beberapa tempat (Jun, et. al, 2005). Habitat ikan coelacanth yang tertangkap di perairan Laut Sulawesi, terdapat di sekitar Pulau Manado Tua, perairan Malalayang, Teluk Manado. Ikan ini tertangkap pada kedalaman lebih dari 180 meter dengan suhu maksimal $18^{\circ} \mathrm{C}$ (Masengi, 2009).

Sampai saat ini penelitian tentang coelacanth dan lingkungan ditemukannya ikan ini masih kurang, oleh sebab itu hasil penelitian ini diharapkan dapat memberikan informasi ilmiah yang bermanfaat dalam menduga keberadaan ikan berdasarkan pergerakan arus di daerah habitat ditemukannya coelacanth di sebelah selatan Teluk Manado.

\section{METODE PENELITIAN}

Penelitian ini dilakukan dengan mengikuti metode deskriptif yang didasarkan pada studi kasus.
Metode deskriptif adalah suatu metode dalam meneliti suatu objek yang tujuannya untuk memberikan gambaran secara sistematik, membuat prediksi dan mendapatkan makna serta implikasi dari masalah yang diselidiki, sedangkan studi kasus adalah mempelajari kasus tertentu pada objek yang terbatas (Surya, 2006).

Pengambilan data dilaksanakan pada siang hari dan malam hari yang dilakukan pada dua titik lokasi pengambilan data yaitu, lokasi pengambilan data pasang surut dan gelombang pada titik $1^{\mathrm{O}} 27^{\prime}$ $39,90^{\prime \prime} \mathrm{N}, 124^{\circ} 49^{\prime} 7,84^{\prime \prime}$ E di daerah pesisir pantai dan lokasi pengambilan data arus pada area $1^{\mathrm{O}} 28^{\prime}$ $22,86^{\prime \prime} \mathrm{N}, 124^{\circ} 48^{\prime} 40,6$ " E $( \pm 0,82$ mil laut dari pesisir pantai).

Pengumpulan data dilakukan dengan mengoperasikan 3 alat ukur, yaitu pengukur arus, pengukur pasang surut dan pengukur gelombang.

Pengukuran arus

Pengukuran arus dilakukan dengan pengukur floater current meter dengan menggunakan dua metode yaitu metode lagrangian dan eularian. Interval pengukuran dilakukan pada 10 menit, 20 menit, 30 menit dan kemudian 1 jam. Posisi-posisi tersebut disimpan dalam memori GPS (Global Position System) sebagai waypoints. Bersamaan dengan penentuan posisi, jam penentuan posisi untuk floater dicatat pertama dengan cara mengambil titik GPS lokasi sebelum floater dilepaskan, kemudian floater yang telah dipasang tali kontrol 'monofilament' nomor 300 sepanjang $350 \mathrm{~m}$ dilepaskan dan dibiarkan hanyut selama kurang lebih 1 jam dengan asumsi tali kontrol tidak mempengaruhi pergerakan arus, pengukuran ini dihitung menggunakan stopwatch selama waktu yang ditentukan. Setelah sampai waktu yang ditentukan floater kemudian diambil posisinya dengan menggunakan GPS sebagai titik akhir yang menjadi jarak pergerakan arus. Cara ini diulangi sampai 5 kali dengan interval waktu yang berbeda. Pengukuran metode eularian dilakukan dengan cara mengambil titik GPS untuk melepaskan floater yang telah ditentukan dengan ukuran panjang tali 'monofilament' 5 m nomor 300 sebagai tali kontrol dengan asumsi tidak mempengaruhi pergerakan arus, sambil menghidupkan stopwatch secara bersamaan pada saat pelepasan floater. Setelah tali mengalami ketegangan (strech), stopwatch dihentikan dan waktu tersebut menjadi waktu kecepatan arus. Kemudian arah arus diukur menggunakan kompas bidik dari posisi floater dilepaskan ke arah hanyutan floater, metode ini dilakukan 5 kali ulangan pada setiap waktu 
pengukuran untuk mendapatkan kisaran rata-rata kecepatan arus. Pengukuran ini dilakukan sebanyak 5 kali pengulangan setiap waktu pelepasan, dengan antara waktu pelepasan 30 menit pada titik GPS yang sama dengan pelepasan awal. Hasil dari pengukuran arus dijelaskan dengan metode mawar arus dimana arah panah menunjukkan arah arus sedangkan panjang panah adalah kecepatan arus (Kelana, 2019).

\section{Pengukuran pasang surut}

Pengambilan data ini dilakukan selama 24 jam. Perubahan tinggi muka air yang berkaitan dengan pasang surut diukur dengan palem pasut. Pembacaan tinggi pasang surut dilakukan setiap 60 menit selama siang hari pada saat pengoperasian pelampung-pelampung arus.

\section{Pengukuran gelombang}

Pengambilan data ini dilakukan pada pukul 17.00 WITA sampai dengan pukul 18.00 WITA. Cara mengukur gelombang yaitu pada saat puncak gelombang atau lembah datang menghampiri tiang besi, maka sterofoam mengalami fluktuasi naik (titik tertinggi) dan pada saat sterofoam turun (titik terendah) dilakukan pencatatan skala tinggi dan rendahnya puncak gelombang. Pengukuran ini dilakukan selama 70 kali lembah/puncak gelombang.

Analisis data dihitung dengan koordinat geografis saat floater current meter dilepaskan, dan koordinat geografis beberapa menit sesudahnya. Dengan kaidah trigonometri, diperoleh jarak tempuh floater dalam selang waktu yang ditentukan, sehingga kecepatan gerak floater adalah kecepatan arus itu dapat dihitung. Sedangkan untuk arah arus, diperoleh dengan memplot data posisi yang terekam di GPS (Kelana, 2019). Untuk menghitung kecepatan arus diperoleh dengan perbandingan antara nilai, jarak, dan waktu yang ditempuh oleh floater current meter sejauh 5 meter (Sudarto, 1993) dengan:

$$
V=\frac{L}{T}
$$

Dimana:

$\mathrm{V}=$ Kecepatan arus $(\mathrm{m} / \mathrm{d})$

$\mathrm{L}=$ Jarak tempuh "current drouge" (meter)

$\mathrm{T}=$ Waktu yang ditempuh oleh current drouge (detik)

Untuk analisis data pasang surut di petakan pada grafik sumbu X dan Y. Dimana Sumbu X adalah waktu pengamatan setiap satu jam sedangkan sumbu Y adalah tinggi pasang surut. Berdasarkan pengukuran tinggi muka air sebanyak 24 kali, diperoleh nilai tinggi rata-rata muka air, mean sea level (MSL) sesuai dengan formula Hasriyanti (2015) di bawah ini:

$\mathrm{MSL}=\frac{\sum_{t-1}^{24} \mathrm{HiCi}}{\sum_{t-1}^{24} C i}$ atau $\mathrm{MSL}=\Sigma \mathrm{HMean} / \mathrm{N}(\mathrm{cm})$

Dimana:

MSL = Tinggi muka air rata-rata

$\mathrm{H} \quad=$ Tinggi muka air saat pengukuran

$\mathrm{N}$ = Jumlah pengamatan

Untuk menganalisa parameter gelombang diukur tinggi maximum, tinggi minimum dan panjang gelombang, yang kemudian dihitung analisis energi gelombang yang terjadi saat pengukuran menggunakan Sverdrup, et. al (1955):

e Gel $=1 / 2$ g. $\rho$. $s w H$

Dimana:

$\mathrm{g}=$ Gravity. percepatan gravitasi bumi, $(\mathrm{g}=$ $9.8 \mathrm{~m} / \mathrm{det} 2)$

$\rho \quad=$ Density $(1,02-1,07 \mathrm{gr} / \mathrm{cm} 3)$

$\mathrm{swH}=$ Tinggi gelombang nyata

Analisis ketiga parameter fisik kelautan tersebut dianalisis menggunakan piranti lunak Excel 2007 dan Canvas Pro. v9.0.3.

\section{HASIL DAN PEMBAHASAN}

Berdasarkan hasil analisis dari penelitian ini dijabarkan sebagai berikut:

\section{Arus}

Hasil dari pengukuran arus ditampilkan dalam tabel 1, 2, dan 3 dengan pergerakan arus pada gambar 1, 2, dan 3. Gambar tersebut menjelaskan arah panah untuk menunjukkan arah arus, sedangkan panjangnya panah kecepatan arus dalam satuan.

Data pada Tabel 1 dengan menggunakan simulasi mawar arus seperti terlihat pada Gambar 1, dimana gambar arah panah menunjukkan arah arus berdasarkan arah kompas bidik cenderung menuju ke arah pesisir pantai, sedangkan panjang panah menunjukkan kecepatan arus. Penomoran 1-5 menjelaskan urutan waktu pengambilan data arus. Gambar menunjukkan arus tercepat pada pengukuran ke-2 dengan kecepatan arus 0.112 
$\mathrm{m} /$ detik mengarah ke barat barat daya sedangkan kecepatan yang paling lambat terdapat pada pengukuran arus ke-5 dengan kecepatan 0.033 $\mathrm{m} /$ detik bergerak ke arah selatan menenggara. Hal ini dimungkinkan karena pada waktu pengukuran dilakukan saat menjelang air surut sehingga arus pada pengambilan data ke-5, kecepatan arus menjadi lebih lambat.

Hasil analisis teknik pengambilan data ke-2 dapat dilihat pada Tabel 2 dengan simulasi mawar arus pada Gambar 2.

Tabel 1. Hasil perhitungan rata-rata kecepatan mawar arus (m/det) dengan metode eularian pada umur bulan 15 .

\begin{tabular}{cccll}
\hline No & Waktu & $\begin{array}{l}\text { Rata-rata } \\
\text { arah arus } \\
\left({ }^{\circ}\right)\end{array}$ & $\begin{array}{l}\text { Rata-rata } \\
\text { waktu arus } \\
\text { (detik) }\end{array}$ & $\begin{array}{l}\text { Rata-rata } \\
\text { kecepatan } \\
\text { arus } \\
(\mathrm{m} / \text { detik })\end{array}$ \\
\hline 1. & $09.30-10.00$ & 228.2 & 48.020 & 0.104 \\
2. & $10.00-10.30$ & 246.0 & 44.654 & 0.112 \\
3. & $10.30-11.00$ & 208.0 & 57.044 & 0.088 \\
4. & $11.00-11.30$ & 194.0 & 96.654 & 0.052 \\
5. & $11.30-12.00$ & 166.0 & $15 ., 875$ & 0.033 \\
\hline
\end{tabular}

Tabel 2. Hasil pengukuran rata-rata kecepatan mawar arus (m/det) dengan metode eularian pada umur bulan 21 .

\begin{tabular}{|c|c|c|c|c|}
\hline No & Waktu & $\begin{array}{l}\text { Rata-rata } \\
\text { arah arus } \\
\left(^{\circ}\right)\end{array}$ & $\begin{array}{l}\text { Rata-rata } \\
\text { waktu arus } \\
\text { (detik) }\end{array}$ & $\begin{array}{l}\text { Rata-rata } \\
\text { kecepatan } \\
\text { arus } \\
(\mathrm{m} / \text { detik })\end{array}$ \\
\hline 1. & $20.30-20.50$ & 84 & 43.746 & 0.114 \\
\hline 2. & $21.30-21.55$ & 108 & 75.065 & 0.067 \\
\hline 3. & $23.00-23.30$ & 44 & 68.615 & 0.073 \\
\hline 4. & $01.00-01.30$ & 304 & 42.036 & 0.119 \\
\hline 5. & $02.00-02.30$ & 324 & 76.302 & 0.066 \\
\hline
\end{tabular}

Data pada Tabel 2 dengan menggunakan simulasi mawar arus seperti terlihat pada Gambar 2, menjelaskan arah arus berdasarkan arah kompas bidik cenderung ke arah laut. Gambar 2 menjelaskan arus tercepat terdapat pada pengukuran arus ke-4 dengan kecepatan 0.119 m/detik mengarah ke barat laut dan arus untuk kecepatan paling lambat dengan kecepatan arus $0.066 \mathrm{~m} /$ detik ada pada pengukuran arus ke-5 menuju kearah utara barat laut. Hal ini dimungkinkan karena pada waktu tersebut terjadinya saat menjelang surut terendah dan pengaruh daya tarik bulan dimana pada saat tersebut bulan berada hampir tegak lurus dengan posisi membentuk sudut $\pm 80 \mathrm{o}$. Pengaruh daya tarik bulan dapat dibuktikan dengan adanya pergerakkan arus pada pengambilan data awal pada pukul 20.30 WITA arus bergerak kearah tenggara, pada saat tersebut bulan belum nampak. Semakin larut malam bersamaan dengan kemunculan bulan arah arus mulai berubah ke arah barat laut.

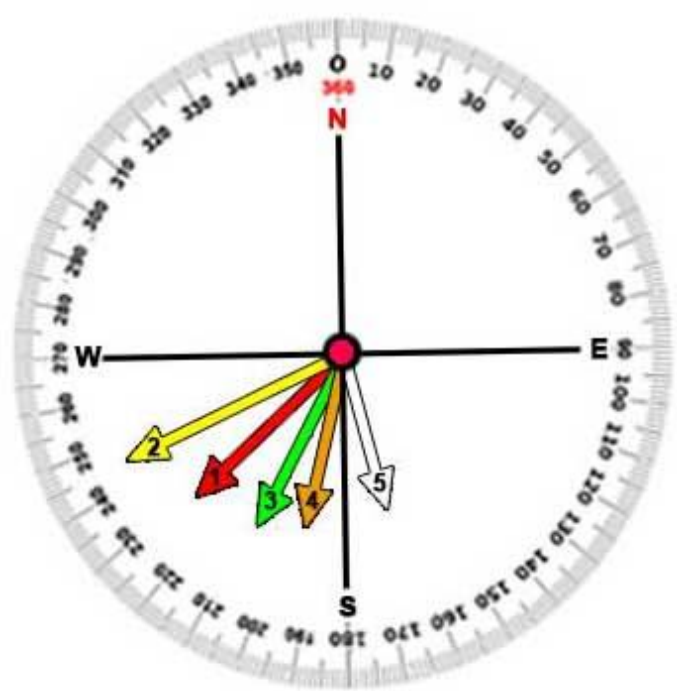

Gambar 1. Mawar arus umur bulan 15 dengan metode eularian (modifikasi Canvas Pro. v9.0.3).

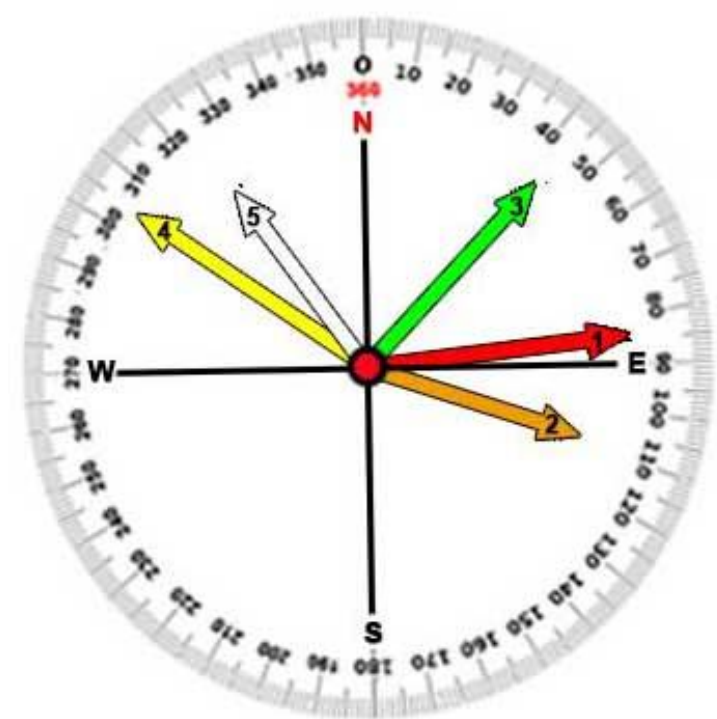

Gambar 2. Mawar arus umur bulan 21 dengan metode eularian (modifikasi Canvas Pro. v9.0.3). 
Pengambilan data arus dengan metode lagrangian dilakukan pada saat yang sama dan hasilnya dapat dilihat pada Tabel 3 dengan simulasi pola arus pada Gambar 3.

Tabel 3. Hasil pengukuran rata-rata kecepatan arus dengan metode lagrangian pada umur bulan 21 .

\begin{tabular}{|c|c|c|c|c|c|c|c|}
\hline & No & Waktu & Titik awal & Titik akhir & Jarak (m) & $\begin{array}{c}\text { Waktu } \\
\text { pengukuran } \\
\text { (detik) }\end{array}$ & $\begin{array}{c}\text { Kecepatan arus } \\
\text { (m/detik) }\end{array}$ \\
\hline \multirow[t]{2}{*}{ 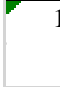 } & 1. & \multirow[t]{2}{*}{$20.50-21.30$} & $\mathrm{~N}: 01^{\circ} 28^{\prime} 23,71^{\prime \prime}$ & $\mathrm{N}: 01^{\circ} 28^{\prime} 25,15^{\prime \prime}$ & \multirow[t]{2}{*}{343} & \multirow[t]{2}{*}{1025.466} & \multirow[t]{2}{*}{0.334} \\
\hline & & & E : $124^{\circ} 48^{\prime} 50,11^{\prime \prime}$ & $\mathrm{E}: 124^{\circ} 48^{\prime} 39,09^{\prime \prime}$ & & & \\
\hline \multirow{2}{*}{\multicolumn{2}{|c|}{2}} & \multirow[t]{2}{*}{$22.00-23.00$} & $\mathrm{~N}: 01^{\circ} 28^{\prime} 25,15^{\prime \prime}$ & $\mathrm{N}: 01^{\circ} 28^{\prime} 33,99^{\prime \prime}$ & \multirow[t]{2}{*}{315} & \multirow[t]{2}{*}{2351.406} & \multirow[t]{2}{*}{0.134} \\
\hline & & & E : $124^{\circ} 48^{\prime} 39,09^{\prime \prime}$ & $\mathrm{E}: 124^{\circ} 48^{\prime} 44,18^{\prime \prime}$ & & & \\
\hline \multirow[t]{2}{*}{ 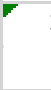 } & 3. & \multirow[t]{2}{*}{$23.30-00.50$} & $\mathrm{~N}: 01^{\circ} 28^{\prime} 33,99^{\prime \prime}$ & $\mathrm{N}: 01^{\circ} 28^{\prime} 32,15^{\prime \prime}$ & \multirow[t]{2}{*}{369} & \multirow[t]{2}{*}{4104.000} & \multirow[t]{2}{*}{0.090} \\
\hline & & & E : $124^{\circ} 48^{\prime} 44,18^{\prime \prime}$ & $\mathrm{E}: 124^{\circ} 48^{\prime} 32,42^{\prime \prime}$ & & & \\
\hline \multirow{2}{*}{\multicolumn{2}{|c|}{4}} & \multirow[t]{2}{*}{$01.30-02.00$} & $\mathrm{~N}: 01^{\circ} 28^{\prime} 32,15^{\prime \prime}$ & $\mathrm{N}: 01^{\circ} 28^{\prime} 34,52^{\prime \prime}$ & \multirow[t]{2}{*}{274} & \multirow[t]{2}{*}{1285.500} & \multirow[t]{2}{*}{0.213} \\
\hline & & & E : $124^{\circ} 48^{\prime} 32,42^{\prime \prime}$ & E : $124^{\circ} 48^{\prime} 23,80^{\prime \prime}$ & & & \\
\hline \multirow{2}{*}{\multicolumn{2}{|c|}{5}} & \multirow[t]{2}{*}{$02.30-03.10$} & $\mathrm{~N}: 01^{\circ} 28^{\prime} 34,52^{\prime \prime}$ & $\mathrm{N}: 01^{\circ} 28^{\prime} 32,06^{\prime \prime}$ & \multirow[t]{2}{*}{11.6} & \multirow[t]{2}{*}{2161.200} & \multirow[t]{2}{*}{0.005} \\
\hline & & & $\mathrm{E}: 124^{\circ} 48^{\prime} 23,80^{\prime \prime}$ & $\mathrm{E}: 124^{\circ} 48^{\prime} 38,30^{\prime \prime}$ & & & \\
\hline
\end{tabular}

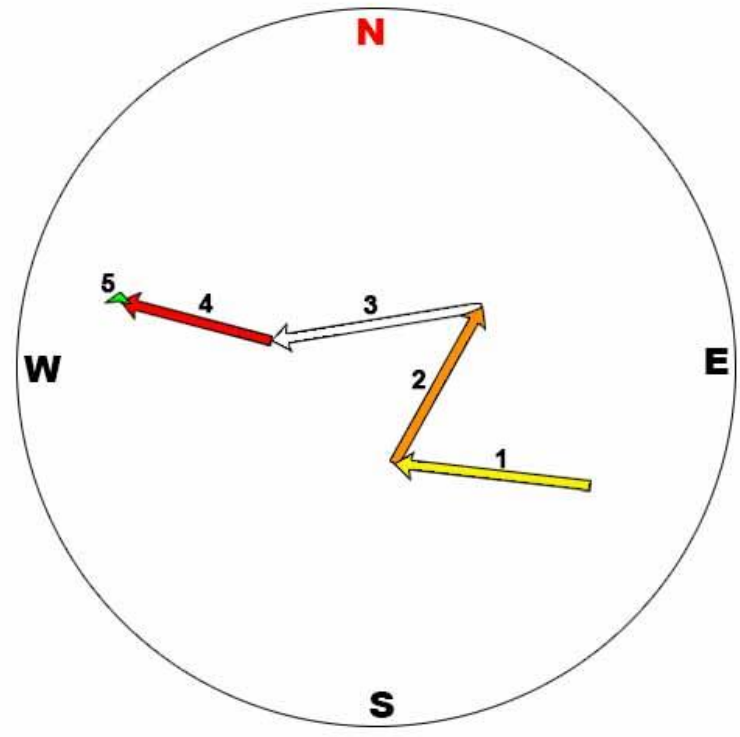

Gambar 3. Pola arus umur bulan 21 dengan metode lagrangian (modifikasi Canvas Pro. v9.0.3).

Gambar 3 memperlihatkan pola arus yang berbeda dibandingkan pengukuran yang dilakukan dengan metode eularian, dimana panjang panah menunjukkan kecepatan arus berdasarkan skala titik koordinat GPS yang diolah dalam program canvas untuk mendapatkan hasil pola arus yang cenderung ke arah barat laut dimana arah arus panah no 1 pada pengambilan data pertama merupakan kecepatan arus tertinggi yaitu 0.334 $\mathrm{m} /$ detik ke barat barat laut, kemudian pada panah ke-2 ditunjukkan arah arus berubah ke arah utara timur laut dengan kecepatan lebih rendah dari yang pertama yaitu $0.134 \mathrm{~m} /$ detik. Pada panah ke-3 kecepatan arus semakin lambat yaitu $0.090 \mathrm{~m} /$ detik ke barat barat daya, hal ini dimungkinkan karena pada saat tersebut adalah saat kemunculan bulan di langit. Pada saat pengukuran ke-4, arah arus berbelok ke arah barat barat laut dengan kecepatan $0.213 \mathrm{~m} /$ detik dan pengukuran ke-5 memiliki kecepatan arus $0.005 \mathrm{~m} /$ detik ke utara, hal ini dimungkinkan karena pada saat tersebut terjadi pasut terendah.

Hasil analisis pergerakkan pola arus yang mengarah ke barat laut menjelaskan kemungkinan pergerakkan perpindahan ruaya ikan Latimeria menadoensis dari habitat awal yang ditemukan di perairan sekitar Pulau Manado Tua yang bermigrasi ke daerah dekat pesisir pantai Bahu mengarah ke Malalayang dan seterusnya ke Tateli. Hal ini sesuai dan mendukung hasil beberapa survey tentang keberadaan dan ditemukannya Latimeria menadoensis sejak tahun 2005- 2015 sebanyak empat individu (Iwata, et al, 2019).

\section{Pasang surut}

Pasang surut di daerah ini bersifat semidiurnal atau harian ganda pada Gambar 4 dengan tinggi gelombang pasut sekitar $61.46 \mathrm{~cm}$.

Hasil pengukuran data pasang surut menunjukkan tipe pasang surut adalah semi diurnal atau harian ganda sebesar 51.04, dihitung dengan menggunakan formulasi sebagai berikut:

$\mathrm{MSL}=\frac{1225}{24}=51.04 \mathrm{~cm}$ 


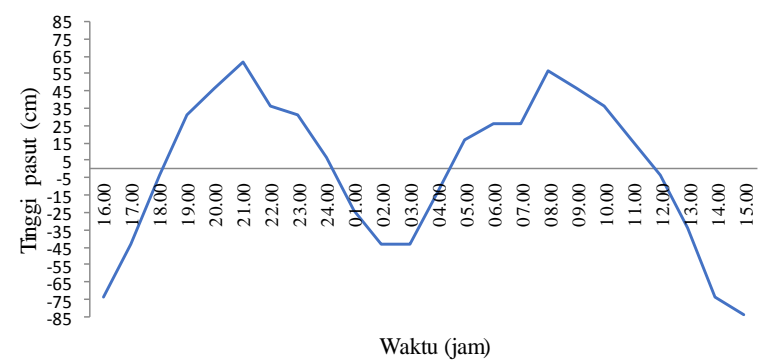

Gambar 4. Hasil Pengukuran Pasang Surut.

\section{Gelombang}

Hasil pengamatan yang dilakukan sebanyak 70 kali pembacaan gelombang dengan waktu sekitar 60 menit diperoleh titik tertinggi gelombang sebesar $42 \mathrm{~cm}$ dan titik terendah $-28 \mathrm{~cm}$, dapat dilihat pada Gambar 5.

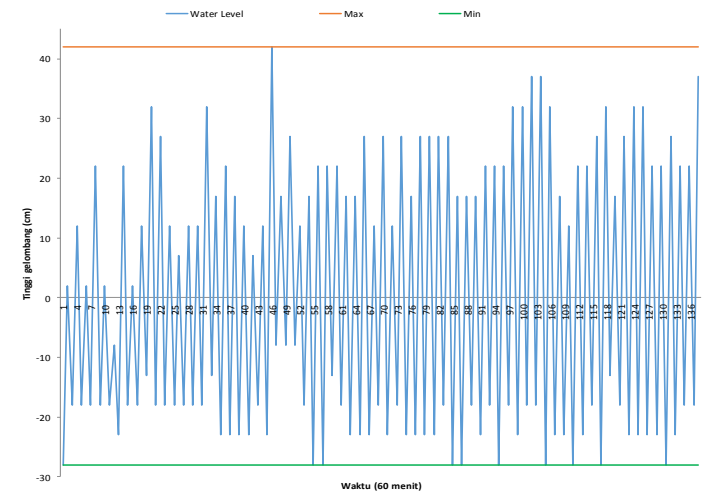

Gambar 5. Hasil pengukuran data gelombang

Berdasarkan analisis data yang diambil, menggunakan rumus no 3 , maka didapat energi rata-rata gelombang sebesar 1.46 joule per gelombang dengan energi gelombang tertinggi pada pengukuran ke 24 sebesar 8.5 joule dan energi gelombang terendah ada pada pengukuran pertama yaitu sebesar 5 Joule.

\section{KESIMPULAN}

Hasil penelitian ini menunjukkan pergerakkan arus dengan metode eularian didominasi oleh pergerakkan arus dari arah barat laut ke timur pada saat perbani akhir atau umur bulan ke 21. Kondisi tersebut sangat bertolak belakang pada saat umur bulan 15 atau purnama. Tipe pasang surut di lokasi penelitian adalah semi diurnal yaitu terjadi dua kali pasang dan dua kali surut. Kecepatan arus berkisar antara $0.033-0.112 \mathrm{~m} /$ det dengan energi rata-rata gelombang sebesar 1.46 joule per gelombang. Berdasarkan kajian pergerakkan arus di habitat ikan coelacanth di sebelah selatan Teluk Manado nampaknya pergerakkan coelacanth didukung oleh hasil kajian pergerakkan arus dimana ikan coelacanth ini berkemungkinan beruaya dari arah Pulau Manado Tua dan Bunaken ke Pantai Bahu, Malalayang terus ke arah pantai Tateli.

\section{UCAPAN TERIMA KASIH}

Ucapan terima kasih kepada bapak Karter yang sudah membantu dalam proses penelitian dan sudah memberikan fasilitas dalam pelaksanaan penelitian.

\section{DAFTAR PUSTAKA}

Garrison T. 1993. Oceanography, an invitation to marine science. Wadsworth inc, California.

Geyer W.R. 1997. Influence of wind on dynamics and fluishing of shallow estuaries. Estuarine, coastal and shelf science 44(6): 713-722

Hariyanti. 2015. Tipe gelombang dan pasang surut di perairan pulau dutungan kabupaten barru Sulawesi Selatan. Jurnal Sainsmat Vol. IV, No.1. Hal 14-27.

Inoue G. J. Miya M. VenkateshbB. Nishida M. 2005. The mitochondrial genome of Indonesian coelacanth Latimeria menadoensis (Sarcopterygii: Coelacanthiformes) and divergence time estimation between the two coelacanths. Jurnal Gene Vol. 349. 11 April 2005. Pages 227-235.

Iwata. et al. 2019. Observation of the first juvenile Indonesian coelacanth, Latimeria menadoensis from Indonesian waters with a comparison to embryos of Latimeria chalumnae. Jurnal Bull. Kitakyushu Mus. Nat. Hist. Hum. Hist., Ser. A, 17: 57-65.

Kalangi P.N.I dan J. Budiman. 2000. Arus permukaan di perairan Pantai Tanjung Kelapa kecamatan Tombariti Minahasa. Jurnal Fakultas Perikanan Unsrat. II (1):29-33.

Kalangi P.N.I. 2000. Surface divergence in Port Philip Bay. Jurnal Fakultas Perikanan Unsrat II (1):34-38.

Kelana Putra. 2019. Arus dan gelombang air laut 1. Academia. https://www.academia.edu/9110059/arus_dan_gelombang _air_laut. Diakses tanggal 10 April 2019.

Masengi K.W.A. 2009. https://regional.kompas.com/read/ 2009/09/14/20554485/ikan.purba.coelacanth.ditemukan. lagi. Diakses tanggal 4 January 2013.

Nontji A. 1993. Laut nusantara. Djambatan. Jakarta.

Sudarto. 1993. Pembuatan alat pengukur arus secara sederhana. Ocean Vol XVIII, Nomor 1:35-44.

Surya S. 2006. Panduan menulis Skripsi, Tesis, Disertasi dan Karya Ilmiah. Pustaka Pena, Jogjakarta. 118 hal.

Sverdrup M. W. Johnson R. H. 1955. The oceans their physics chemistry and general biology $H$. U. Fleming sixth printing hardcover 